\title{
Climate protection as an opportunity for banks to increase earnings and consumer trust
}

\section{Introductory overview}

Climate change is one of the most pressing topics in society and the resulting sustainability risks pose great challenges for the financial sector (BaFin 2018; Waschbusch et al. 2020a, 406). The term 'sustainability' in general includes three dimensions: 'economic sustainability', 'environmental sustainability' and 'social sustainability' (Rauschenberger 2002, 6; Hesse 2008, 5; Hauff 2014, 12-13 and 164; Stoffel 2014, 49; Bauer, Stegmaier 2016, 7-8; Schuster, Hastenteufel 2019, 112; Waschbusch et al. 2020b, 616). These so-called three pillars of sustainability are given equal consideration and are therefore equally important for firms (see Figure 1).

Therefore, sustainability risks are defined as events or conditions in the fields of environment, social affairs, or corporate governance, the occurrence of which can actually or potentially have negative effects on asset, financial and earnings positions as well as on a company's reputation (BaFin 2020, 13). However, primarily climate and environmental risks are associated with this risk category (Röseler 2019, 22; Waschbusch et al. 2020b, 618). Environmental sustainability risks can be roughly divided into physical and transitory risks. While physical

\footnotetext{
* Saarland University, e-mail: sabrina.kiszka@bank.uni-saarland.de

** IU International University of Applied Sciences and a private lecturer at Saarland University, e-mail jessica.hastenteufel@iu.org
} 
risks arise from individual weather phenomena with increasing frequency (e.g. periods of heat and drought, floods or storms) and long-term changes in climatic conditions (e.g. rise in sea level), the transitory risks result from the conversion to a low-carbon economy and the associated changing political frameworks as well as the stigmatization of established technologies (Jaeggi et al. 2016, 451; Roettmer 2016, 244; Bank of England 2018, 7 and 17-20; Röseler 2019, 22; BaFin 2020, 14 ; Waschbusch et al. 2020b, 618). Thus, the effects of climate change can have both, a direct impact and indirect consequences for the risk universe of financial institutions, as illustrated in Table 1.

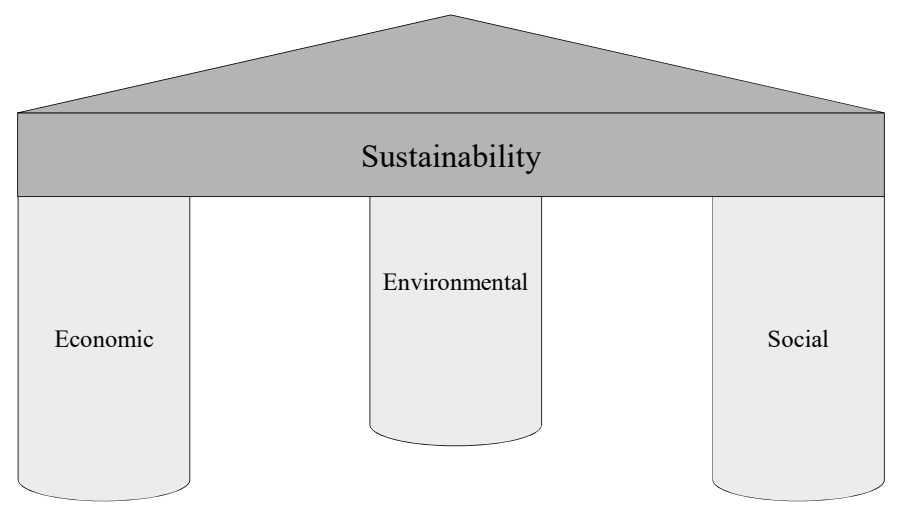

Figure 1. The three pillars of sustainability (Hauff 2014, 164)

Consequently, sustainability risks not only have an impact on credit risk, market risk, operational risk and on the liquidity risk of banks, but also have a significant influence on their reputational risk (Bank of England 2018, 17-19 and 22-25; Carney 2018, 2; Beau 2019, 3; Hannemann et al. 2019, 1230; BaFin 2020, 11-15; Waschbusch et al. 2020b, 619). Reputational risk is defined as the risk that the trust in a company and its credibility are damaged due to a certain internal and external perception (Kiszka 2018, 27-29; Weber, Bopp 2019, B9). In this context, the change in the values of society is a key factor. Therefore, ecological, social, and societal issues are becoming more important when regarding the expectations of bank customers (Bopp 2010, 269; Barthruff 2014, 145; Schuster, Hastenteufel 2019, 119; Weber, Bopp 2019, B9). Firms that do not match these new ethical standards are experiencing an increasing loss of acceptance or are even sanctioned by their customers (Blume 2018; Weber, Bopp 2019, B9). 
Table 1

Effects of sustainability risks on the risk universe of banks (Röseler 2019, 23; Waschbusch et al. 2020b, 619)

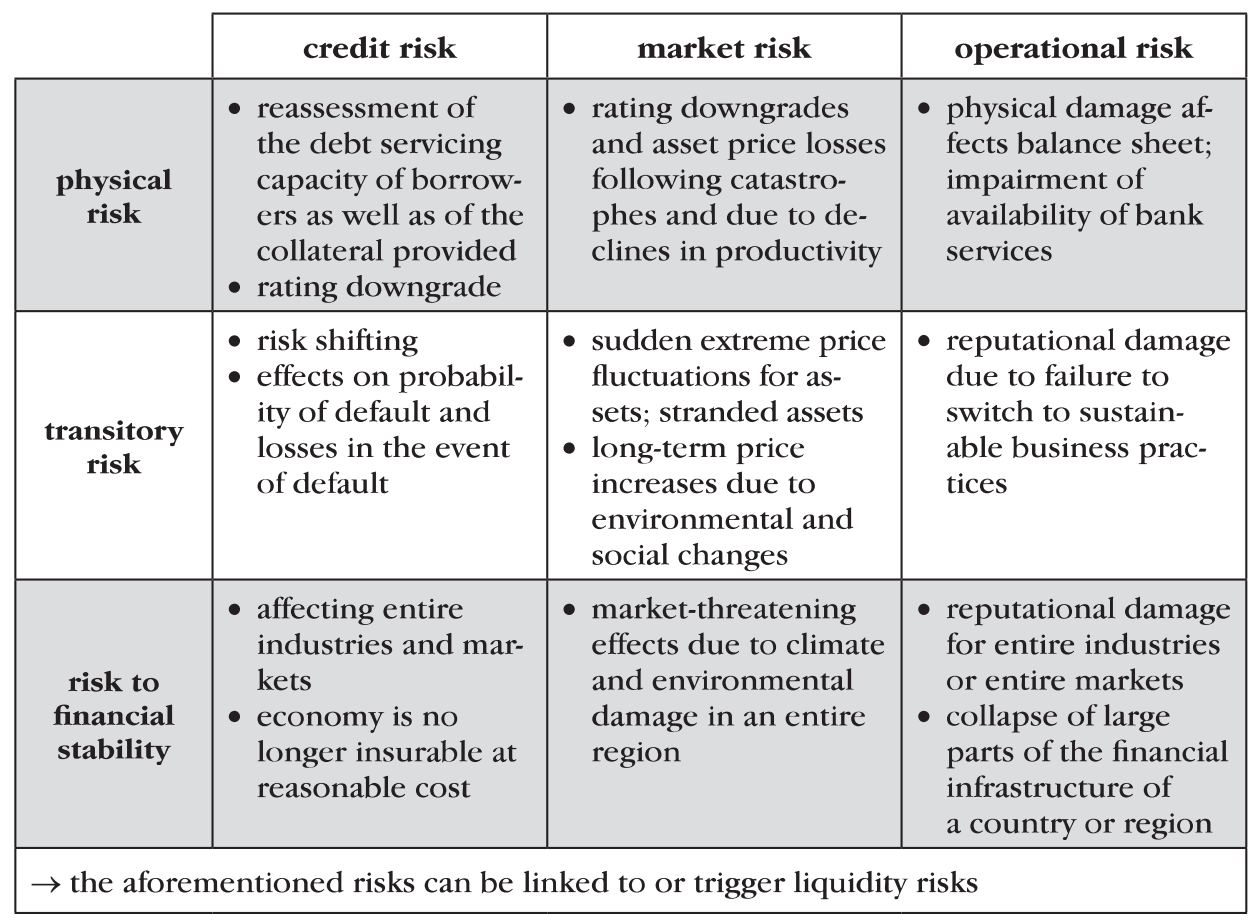

Therefore, based on a study conducted by the authors in Germany this paper examines the expectations bank customers have on how banks deal with the topic of climate protection. As part of this study 1,500 paper questionnaires were given to private individuals. During the distribution of the questionnaires care was taken to ensure that the data are roughly evenly distributed in regard to age and gender. 703 of the received questionnaires were eligible for inclusion in the evaluation.

First it needs to be analysed how customers perceive the importance of banks when it comes to climate protection. Then the perception of climate change by bank customers as well as the willingness of the customers to change their own behaviour to prevent climate change is examined in order to derive the customers' expectations of their banks in general and the advisory services offered in particular. Based on this knowledge some recommendations for the banking industry are made in order to convert the changed value system within society into a long-term opportunity for banks. 


\section{The key role of banks in combating climate change}

While manufacturing companies can contribute to combating climate change through a sustainable design of the supply chain, production or the use of raw materials in their firms, financial institutions have different options to act sustainably. Through their investment and financing activities, they highly influence companies, organizations and entire countries with regard to the implementation of their respective sustainable goals. Due to the potential of this immense cash flow, banks play a key role in creating a sustainable economy (Frese, Colsman 2018,12 ). Therefore, the EU action plan for financing sustainable growth and various national guidelines hold financial market players responsible for archiving this goal (Weber, Bopp 2019, B9). Hence, financial institutions must not only behave sustainably and responsibly themselves but must also ensure that sufficient capital is channelled into sustainable investments. To examine whether bank customers are aware of this role of the financial industry, they were asked to what extent different institutions contribute to climate protection (see Figure 2).

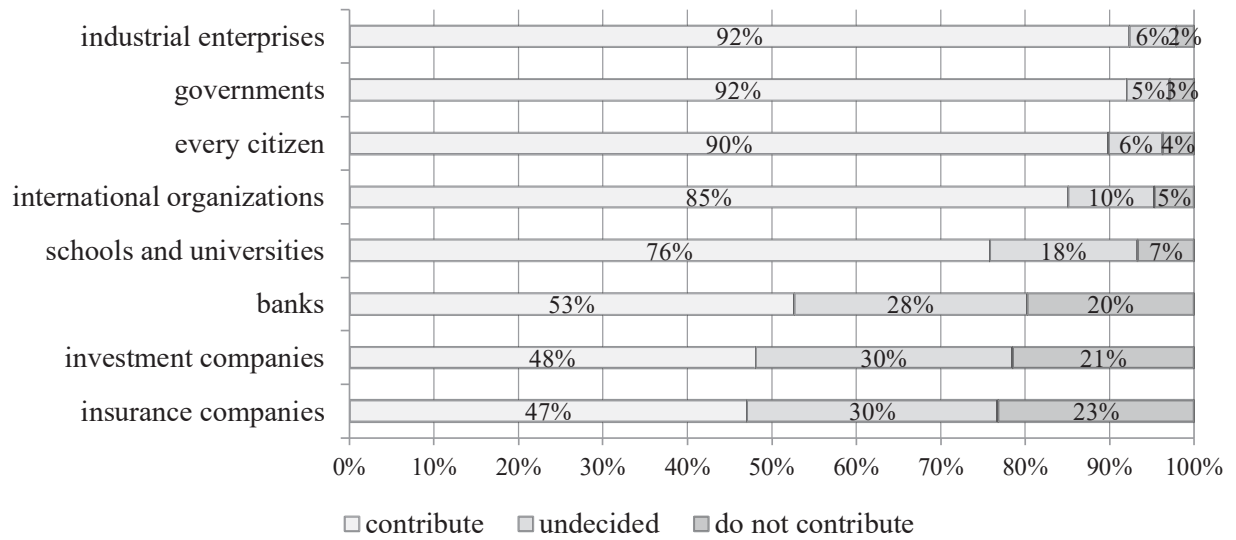

Figure 2. Perceived contribution to climate protection by various institutions

It turns out that industrial enterprises, along with governments, are perceived as the most important institutions in combating climate change. Moreover, the role that every individual citizen can play is also acknowledged. However, the perceived contribution of the financial sector, however, is far behind its actual significance. Only about $50 \%$ of bank customers are convinced that the financial sector (banks, investment companies and insurance companies) can contribute 
to climate protection. This indicates that customers are not aware of the key role played by the financial sector in this context and shows that the influence of financial institutions on the industrial enterprises is obviously not clear to them. This can also be seen in the statement that banks cannot do anything about climate change, which one third of customers agree with. This can be an advantage for banks that have not yet dealt with the topic of climate protection, as customer expectations in this area are rather low at the moment.

Nonetheless, many customers already expect their banks to be and act sustainable. It is important for almost half of the customers surveyed (45.52\%) that their bank is committed to climate protection. In this context, it is becoming apparent that although this commitment is particularly important for younger customers, it is also relevant for other age groups. Thus, banks that are already dealing with the topic of climate change should inform their customers about their own activities and their positive effects on the climate. By doing so, it is important not to conduct greenwashing, but to actually integrate the commitment to climate protection into the business model of a bank and to communicate this integration convincingly. Greenwashing is the attempt to achieve a green image through marketing, but without actually implementing appropriate measures in the context of value creation (n.u. 2019, 1499). In this context, there is a certain scepticism of bank customers. $49.64 \%$ of those questioned state that banks committed to climate protection only do so to gain a positive reputation. It can be stated that those participants who are convinced that it is merely about hoped-for media effects also believe that banks cannot contribute at all to climate protection.

\section{Motivation of bank customers to change their own behaviour}

Bank customers rate the influence of each individual (see Figure 2) as being particularly important. Therefore, it will be discussed to what extent customers themselves are willing to adapt their own behaviour and which implications this entails for banks. In order to understand the motivation for possible changes in their behaviour, the participants' personal attitudes towards climate change are discussed first.

There is a broad consensus among bank customers surveyed that climate change and therefore climate protection are important. It turns out that younger customers tend to rate this topic as more important than older generations. Despite the fundamental awareness of the importance of climate change, only $58.18 \%$ 
of the respondents feel well informed about this topic. The survey results show that customers who describe themselves as well-informed rate climate change as significantly more problematic as customers who feel less informed. Therefore, it can be stated that the better customers are informed, the higher the perceived importance of this topic. There were only a few climate change deniers among the customers surveyed. Only $10.53 \%$ of those questioned doubt that the climate is changing at all. For $12.23 \%$ of the respondents, there are no doubts about climate change per se, only uncertainties about the influence of humankind on climatic changes. About half of the participants are particularly unsure about the effects of climate change. However, the majority of customers $(71.83 \%)$ believes that the effects of the changes in climate will affect them in the near future. Only $12.38 \%$ of the respondents explicitly denied this statement. Moreover, $68.71 \%$ of bank customers are already concerned about being personally affected by these effects in the future.

As $66.43 \%$ of customers are aware that they can contribute to climate protection due to their own behaviour, $20.20 \%$ were undecided in this context, and only a small number of customers do not believe that their behaviour can contribute to climate protection. Furthermore, the vast majority of customers $(75.39 \%)$ is willing to adapt their behaviour in favour of climate protection. The figures show that even customers who are not fully aware of the influence of their behaviour on climate protection are willing to make changes. This may be due to the perceived threat from climate change and the high media presence of this topic in the last years before the corona pandemic started. The general motivation of the respondents to reconsider their behaviour and, if necessary, to adjust it, is underlined by the fact that only a small part of bank customers $(6.12 \%)$ think that climate change cannot be stopped and that behavioural changes will no longer lead to positive results.

Figure 3 provides an overview of individual areas in which each citizen can adapt his or her behaviour, and thus, contribute to climate protection. When asked about the importance of individual fields of action for climate protection, bank customers generally determined the order shown below.

It turns out that the use of renewable energies and alternative means of transport such as public transport and electric or hybrid vehicles are seen as expedient. Customers also consider the reduction in electricity consumption and the increased purchase of regional products to be significant to protect the climate. However, it also shows that the potential of a conscious directing of money flows in sustainable projects is currently not fully understood by customers, since investments in sustainable investment products have been placed lowest in the ranking. 


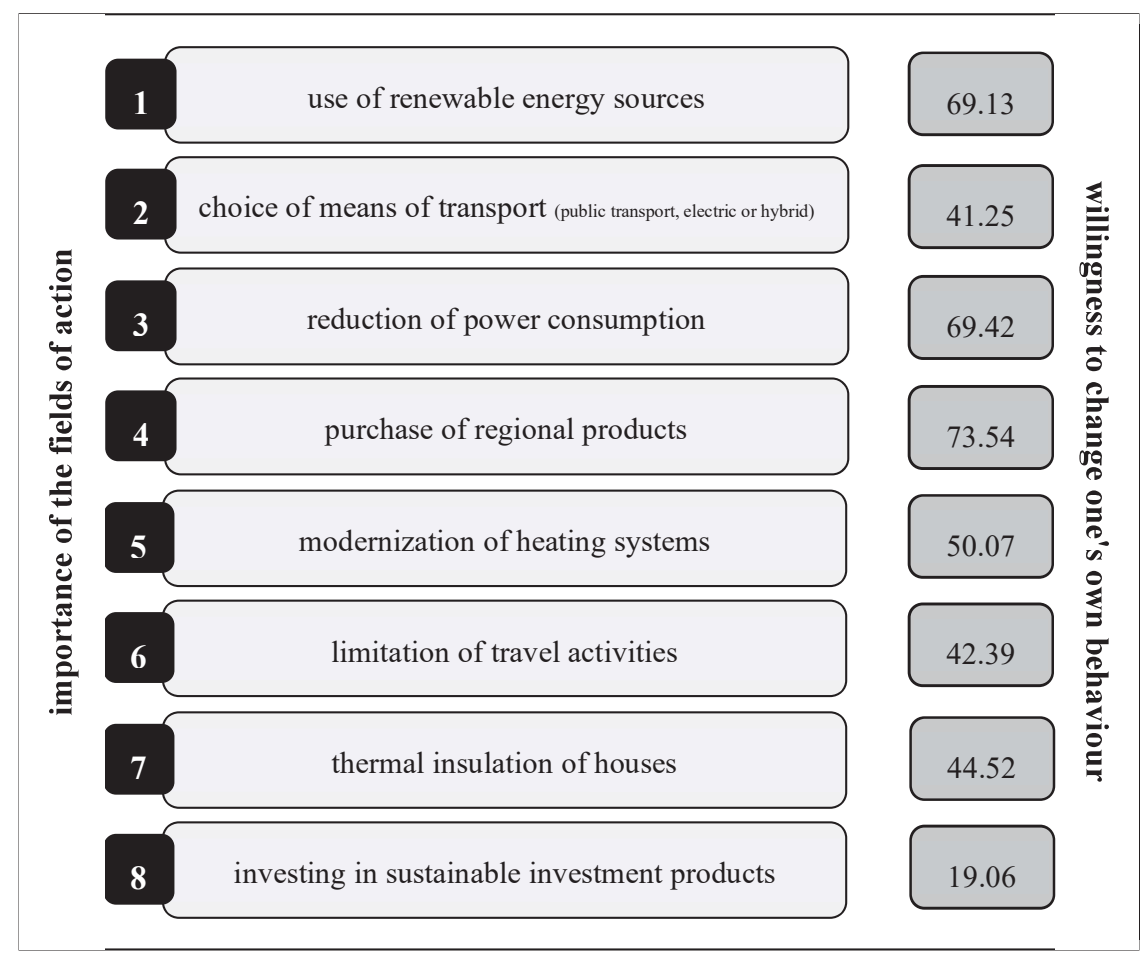

Figure 3. Perceived importance of various fields of action for climate protection and willingness to change own behaviour

The bank customers should also indicate whether they could imagine a change in their behaviour in the different fields of action. The results are illustrated by the values on the right-hand side shown in figure 3 . These values indicate the number of participants who would be willing to adapt their own behaviour in favour of climate protection in this specific field of action. The majority of participants are willing to buy more regional products $(73.54 \%)$, to reduce electricity consumption (69.42\%) and to switch to renewable energy resources (69.13\%). They are also open to modernizing their homes (50.07\%, respectively $44.52 \%)$. However, less than half of participants are willing to switch to other means of transport. Limiting travel activities is only an option for $42.39 \%$ of those surveyed. This shows that for many people, climate protection is only relevant as long as their own comfort or pleasure is not restricted. Again, investing in sustainable investment products is least popular. Only $19.06 \%$ of the respondents are considering investing in sustainable investment products. Therefore, the question arises as 
to whether bank customers are averse on sustainable investment products per se or whether the findings are based on other motives.

\section{Willingness to invest in sustainable investment products}

In view of the general interest in the topic of climate change and the willingness to contribute in some form to climate protection by most participants, it is apparent that, due to the lack of understanding of the role of financial institutions in creating a sustainable economy, sustainable investment products do not receive adequate attention by many customers. However, not only the understanding of the complex relationships within the financial system is a problem, but also the respondents' basic understanding of securities in general and the fundamental willingness to invest in them is insufficient. $59.60 \%$ of all participants currently do not invest in securities. However, more than a third of these customers $(37.71 \%)$ would like to invest in securities, but do not feel well enough informed. This reveals a first omission by banks, which in the past few years have apparently not responded to the wishes of their customers and at the same time failed to recognize a large source of income. Even in the current interest rate situation, the banks have not yet succeeded in contacting their customers about these types of investments, and thus, not only failed to optimize the returns of their customers, but also their own earnings potential. The question arises whether this is due to a lack of knowledge of the customer's wishes or because the advisory services offered at the moment are not compatible with the customers' actual needs. However, in this context another study conducted by the authors found that almost half of the customers surveyed do not believe that their bank even knows what they want in financial matters. Therefore, it can be concluded that banks do not seem to ask their customers about current wishes on appropriate occasions, even though this is the basis of any good and holistic advice. In addition, even if the customers' wishes are known, only $42.05 \%$ of bank customers feel that the banks cater specifically to those wishes (Hastenteufel, Kiszka 2020b, 540; Hastenteufel, Kiszka 2020c, 25-26).

Customers are just as open about their lack of knowledge on sustainable investments. $73.83 \%$ of customers feel not sufficiently informed about sustainable investment options by their banks, which underlines the high need for advisory services and the banks' previous inactivity. Only $14.51 \%$ of customers describe their knowledge in this area as good. Therefore, it is not surprising at all that only $6.40 \%$ of all customers surveyed have already bought a sustainable investment product. Although for most customers aspects such as security and 
return on investment are prioritized, $38.98 \%$ of those surveyed state that they are considering integrating environmental aspects in their investment decisions in the future. Obviously, the hesitation to invest in sustainable investments is primarily due to the knowledge gap among bank customers, which credit institutions have not been able to adequately close in the past.

\section{Need for sustainable financial advice}

Almost half of the bank customers surveyed (47.37\%) are interested in sustainable financial products and would like their bank to provide them with more advice and assistance on sustainable investments in order to be aware of such companies and projects that take action against climate change. It should be particularly emphasized that for this purpose customers would also accept being actively contacted by their bank. When visiting a bank branch, $64.15 \%$ of all customers surveyed would not mind being personally approached to be informed about sustainable investment opportunities. Customers also think it is appropriate to be contacted by email (53.34\%), letter (47.08\%) and via online banking (44.24\%). In this regard, younger and middle-aged customers prefer to be contacted by email and via online banking, while older customers aged 56 and above prefer a letter. Nevertheless, the majority of customers - regardless of age, rejects being contacted by a bank employee via telephone. Thus, banks have a large number of contact options at their disposal in order to actively reach out to their customers to inform them on sustainable investment opportunities, and therefore, to enter into a dialogue with their customers in a conscious, needsbased and customer-oriented manner. By doing so, previously inactive customers can be reached again. However, it is up to the banks to identify and satisfy these customer needs.

Sustainable financial advice, however, offers even more sales potential. In the case of new real estate financing, customers want information on energy-saving opportunities, funding programs for energy efficiency and the use and funding of renewable energies. This is in line with the previous results on the personal willingness to change their behaviour, according to which customers are willing to reduce their electricity consumption and switch to renewable energies. Due to the detected willingness to home modernization measures, the above-mentioned advisory services can also be transferred to existing properties, hereby addressing existing customers.

Customers also request insurance-related advice. More than half of the customers would like to receive more support concerning insurance options for technical systems for energy supply such as solar systems as well as insurance 
options against the regional consequences of climate change (see Figure 4). Currently, only one third (34.28\%) of the customers surveyed feel well informed about personal insurance options against climate risks.

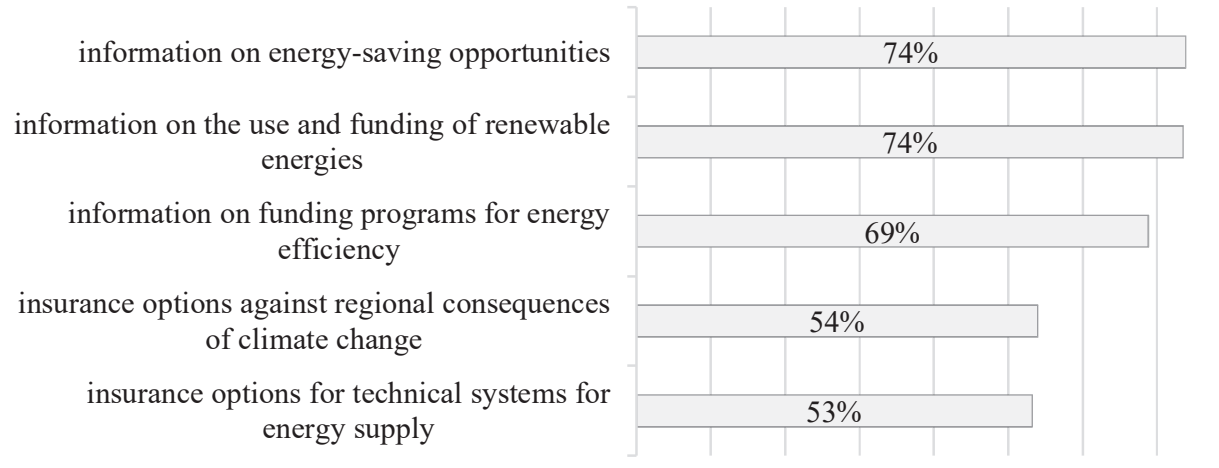

Figure 4. Advisory services requested within real estate financing

Therefore, from a holistic perspective, there is high potential for expanding cooperation with fund companies, development banks and insurance companies. Through sustainable advisory services there is a large, so far (almost) untouched earnings potential for financial institutions, which - especially under the aspect of the decrease in interest income due to the low interest rate environment - focuses on increasing the commission result as well as increasing customer satisfaction and thereby customer loyalty.

\section{Climate protection and taking sustainable actions as a competitive advantage for banks - a critical conclusion}

Already $64.58 \%$ of customers can imagine themselves investing in sustainable investments in the future. $44.95 \%$ of all bank customers are firmly convinced that their personal investment decisions can contribute to climate protection. That is why the majority of customers (56.33\%) want their bank to actively approach them with regard to the possibilities of sustainable investments. Concerning other customers, however, there are some doubts about the earnestness and effectiveness of sustainable investments that need to be resolved. In this context, $31.29 \%$ of bank customers express doubts that sustainable investments can actually 
contribute to climate protection, instead are only an advertising campaign, and consequently only serve to keep the bank in customers' minds. In this regard, projects such as the EU taxonomy for sustainable activities (European Union 2020) are particularly important in order to prevent investments from being declared as green without contributing to sustainability. Especially younger bank customers up to 25 years of age, on whom the future economic success of a bank will largely depend (Matt, Mocha 2019, 1 and 3), are particularly interested in sustainable investments. There is great potential in this customer group, as more than two thirds of younger bank customers do not yet hold any securities, but the desire to do so is particularly pronounced. Sustainable investments also hold an aboveaverage importance for retirees. It can only be speculated whether they place more trust in those banks that promise their children and grandchildren a more sustainable world. Ultimately, the expansion of sustainability across all age groups fails due to the lack of advisory services by the banks in order to explain securities in general and to erase the existing doubts about sustainable investments caused by the knowledge gap on how sustainable products work and the potential they can unfold. Moreover, banks waste earnings potential due to missed opportunities in offering suitable products to those customers who are already willing to invest sustainably.

Furthermore, the customers' wishes regarding sustainability are not limited to investments. Rather, $64.01 \%$ of those surveyed want an all-round advice on the subject of climate change. In order to meet this demand, it is advisable to train some bank advisors to become specialists in sustainable finance, who can then provide comprehensive advisory services to customers either in the branch or digitally. They could also support their colleagues if their specialist knowledge is required. In this context, a close cooperation with the customer advisors of the cooperating investment and insurance companies should be emphasized in order to create the desired all-round advice for the customer. By actively addressing customers concerning sustainable financial advice, banks can not only meet the expectations of their customers, but also address a large number of customers with whom they have no points of contact within the current advisory practice.

Moreover, customers expect climate-friendly behaviour from their banks. The main objective here is to prevent a loss of reputation that can be caused by neglecting sustainable commitments or by pretending to be more sustainable than it is actually the case. Banks should internalize that reputation is an extremely valuable asset that is essential to achieve and maintain customer trust (Imhof 2010, 289). Ultimately, this trust is the basis of any bank's business (Waschbusch et al. $2018,102)$. For this reason, great importance should be attached to the sustainable orientation of the behaviour of financial institutions themselves, as it offers the opportunity to regain the trust lost in the financial crisis (Bethge 2018, 4). 
For $40.54 \%$ of bank customers, a bank that is committed to climate protection appears to be more trustworthy than a bank that is not. $30.87 \%$ of the customers questioned were undecided in this regard, so that only $28.59 \%$ did not agree with this statement. This relatively low number of customers, among other things, can be attributed to the reservations already mentioned that banks only act sustainably in order to obtain positive media effects.

This remarkable trust bonus is even more apparent when the majority of bank customers $(55.76 \%)$ stated that they would rather entrust their money to a bank that is not only focused on its own profits, but also deals with general problems such as climate change. In this way, the sense of responsibility that the financial institutions show in terms of climate protection is transferred to the responsible handling of customer assets. This trust effect is particularly distinct among younger bank customers.

The integration of the sustainability aspect, in particular climate protection, into a bank's customer advisory service, which has so far been rated as inadequate (Hastenteufel, Kiszka 2020a, Hastenteufel, Kiszka 2020b, Hastenteufel, Kiszka 2020c), is an unmistakable competitive advantage, as it offers a noticeable added value for customers. Quick action is required here, as most customers have not yet actively informed themselves about the measures their bank is taking to protect the climate. $24.18 \%$ of the customers are willing to switch to another bank in the future if their bank does not provide them with sustainable financial products and the much needed information and advice, as well as acting sustainably in general. For younger bank customers this figure is even higher (31.63\%).

With the integration of sustainability aspects into banks' advisory services becoming mandatory in the future due to changes in the regulatory framework resulting from the EU action plan for financing sustainable growth (European Commission 2018, 6-7) it is advisable to deal with these sustainability topics as soon as possible. However, the decisive factor for banks to adapt their current advisory concept should not be the regulatory pressure. Taking forward-looking and responsible actions as well as considering climate protection measures within the business model and the advisory service can not only unlock new sources of income and a trust bonus by customers but can also increase customer loyalty and furthermore facilitate new customer acquisition. Therefore, corporate environmental performance can be used as a reputational lever and hereby have a positive impact on financial performance by meeting the demands of relevant stakeholders such as a bank's customers (McWilliams, Siegel 2001, 125; Ortlitzky et al. 2003, 426; Campbell 2007, 962-963; Chernev, Blair 2015, 1421-1422). Thus, the changing value system within society can be transformed into a long-term opportunity for banks. 


\section{References}

[1] BaFin (2018) Nachhaltige Finanzwirtschaft: Veränderungen in Umwelt und Gesellschaft: Umgang der BaFin mit Risiken, [Online], Available: https://www. bafin.de/SharedDocs/Veroeffentlichungen/DE/Fachartikel/2018/fa_bj_1805_ nachhaltige_Finanzwirtschaft.html [04 May 2021].

[2] BaFin (2020) Merkblatt zum Umgang mit Nachhaltigkeitsrisiken, [Online], Available: https://www.bafin.de/SharedDocs/Downloads/DE/Merkblatt/dl_mb_ Nachhaltigkeitsrisiken.pdf [04 May 2021].

[3] Bank of England (2018) Transition in thinking: The impact of climate change on the UK banking sector, [Online], Available: https://www.bankofengland. co.uk/-/media/ boe/files/prudential-regulation/report/transition-in-thinkingthe-impact-of-climate-cha nge-on-the-uk-banking-sector.pdf [04 May 2021].

[4] Barthruff, C. (2014) Nachhaltigkeitsinduzierte Kreditrisiken: Empirische Untersuchung der Wirkungszusammenhänge zwischen Nachhaltigkeits- und Kreditrisiken unter besonderer Berücksichtigung des Klimawandels, Wiesbaden: Springer Gabler.

[5] Bauer, D.A. and Stegmaier, M. (2016) 'Nachhaltigkeit als (Regulierungs-) Konzept im Bankensektor', in Bauer, D.A. and Schuster, G. (ed.) Nachhaltigkeit im Bankensektor: Konzepte, Rechtsfragen, Kulturwandel, Köln: Otto Schmidt.

[6] Beau, D. (2019) Opportunities and risks of evolving sources of financing for the economy, [Online], Available: https://www.bis.org/review/r190329b.pdf [04 May 2021].

[7] Bethge, I. (2018) 'Green Finance ist ein Geschäftsfeld mit Zukunft', Börsen-Zeitung, no. 58 , p. 4.

[8] Blume, J. (2018) Umdenken in der Finanzbranche: Warum Portfoliomanager stärker auf Nachhaltigkeit achten, [Online], Available: https://www. handelsblatt.com/finanzen/ anlagestrategie/nachhaltigegeldanlage/greenbonds-umdenken-in-der-finanzbranche-warum-portfoliomanager-staerkerauf-nachhaltigkeit-achten/22865182.html [04 May 2021].

[9] Bopp, R.E. (2010) 'Die Finanzwirtschaft: Anmerkungen zum Risiko- und Ertragsmanagement von Finanzdienstleistern', in Aßländer, M.S. and Löhr, A. (ed.) Corporate Social Responsibility in der Wirtschaftskrise: Reichweiten der Verantwortung, München/Mering: Rainer Hampp.

[10] Campbell, J.L. (2007) 'Why would corporations behave in socially responsible ways? An institutional theory of corporate social responsibility', Academy of Management Review, vol. 32, pp. 946-967.

[11] Carney, M. (2018) A Transition in Thinking and Action, [Online], Available: https:/www.bis.org/review/r180420b.pdf [04 May 2021].

[12] Chernev, A. and Blair, S. (2015) 'Doing well by doing good: The benevolent halo of corporate social responsibility', Journal of Consumer Research, vol. 41 , pp. 1412-1425. 
[13] European Commission (2018) Action Plan: Financing Sustainable Growth, [Online], Available: https://eur-lex.europa.eu/legal-content/EN/TXT/ PDF/?uri=CELEX:52018D C0097 [04 May 2021].

[14] European Union (2020) Regulation (EU) 2020/852 of the European Parliament and of the Council of 18 June 2020 on the establishment of a framework to facilitate sustainable investments, and amending Regulation (EU) 2019/2088, [Online], Available: https://eur-lex.europa.eu/legal-content/EN/ TXT/PDF/?uri=CELEX:32020R0852\&fr om =DE [04 May 2021].

[15] Frese, M. and Colsman, B. (2018) Nachhaltigkeitsreporting für Finanzdienstleister, Wiesbaden: Springer Gabler.

[16] Hannemann, R., Steinbrecher, I. and Weigl, T. (2019) Mindestanforderungen an das Risikomanagement (MaRisk): Kommentar, $5^{\text {th }}$ edition, Stuttgart: Schäffer-Poeschel.

[17] Hastenteufel, J. and Kiszka, S. (2020a) 'Der Mythos der ganzheitlichen Beratung', bank und markt, vol. 49, pp. 64-68.

[18] Hastenteufel, J. and Kiszka, S. (2020b) 'Die Kundenerwartungen nur unzureichend erfüllt', bank und markt, vol. 49, pp. 537-541.

[19] Hastenteufel, J. and Kiszka, S. (2020c) 'What to German bank customers want?: The importance of customer expectations and the failure of the integral customer advisory service', Managerial Economics, vol. 21, pp. 7-47.

[20] Hauff, M. (2014) Nachhaltige Entwicklung: Grundlagen und Umsetzung, $2^{\text {nd }}$ edition, München: De Gruyter Oldenbourg.

[21] Hesse, A. (2008) 'Globale Herausforderungen für nachhaltige Entwicklung', in Faust, M. and Scholz, S. (ed.) Nachhaltige Geldanlagen: Produkte, Strategien und Beratungskonzepte, Frankfurt am Main: Frankfurt School.

[22] Imhof, K. (2010) 'Globalisierung, Finanzkrise, Öffentlichkeit: Die Rache der Moral', in Aßländer, M.S. and Löhr, A. (ed.) Corporate Social Responsibility in der Wirtschaftskrise: Reichweiten der Verantwortung, München/Mering: Rainer Hampp.

[23] Jaeggi, O., Kruschwitz, N. and Manjarin, R. (2016) 'Der Nutzung von Umwelt- und Sozialrisikomanagement bei Investmentbanken', in Wendt, K. (ed.) CSR und Investment Banking: Investment und Banking zwischen Krise und Positive Impact, Berlin/Heidelberg: Springer Gabler.

[24] Kiszka, S. (2018) Die Steuerung operationeller Risiken in Kreditinstituten: Eine kritische Analyse des neuen Standardansatzes, Wiesbaden: Springer Gabler.

[25] Matt, M. and Mocha, M. (2019) Gefährliche Entfremdung, [Online], Available: https://www.sparkassenzeitung.de/kommunikation/studie-junge-bankkunden-mit-tip ps-gefaehrliche-entfremdung [04 May 2021].

[26] McWilliams, A. and Siegel, D. (2001) 'Corporate social responsibility: A theory of the firm perspective', Academy Management Review, vol. 26, pp. 117-127. 
[27] n.u. (2019) Gabler Wirtschaftslexikon, 19 $9^{\text {th }}$ edition, Wiesbaden: Springer Gabler.

[28] Orlitzky, M., Schmidt, F.L. and Rynes, S. (2003) 'Corporate Social and Financial Performance: A Meta-analysis', Organizational Studies, vol. 24, pp. 403-441.

[29] Rauschenberger, R. (2002) Nachhaltiger Shareholder Value: Integration ökologischer und sozialer Kriterien in die Unternehmensführung und in das Portfoliomanagement, Bern/Stuttgart/Wien: Haupt.

[30] Röseler, R. (2019) Nachhaltigkeit: Herausforderung und Chance für die Kreditwirtschaft, BaFin Perspektiven, no. 2, pp. 19-28, [Online], Available: https://www.bafin.de/dok/12377478 [04 May 2021].

[31] Roettmer, N. (2016) 'Finanzierung von $\mathrm{CO}_{2}$-Emissionen: Ein Geschäftsrisiko?', in Wendt, K. (ed.) CSR und Investment Banking: Investment und Banking zwischen Krise und Positive Impact, Berlin-Heidelberg: Springer Gabler.

[32] Schuster, H. and Hastenteufel, J. (2019) Die Bankenbranche im Wandel: Status Quo und aktuelle Herausforderungen, $2^{\text {nd }}$ edition, Baden-Baden: Nomos.

[33] Stoffel, T. (2014) 'Konzepte von Green Economy und Green Society: Soziale Aspekte Grünen Wirtschaftens im Spannungsfeld von Politik, Wirtschaft und Gesellschaft', in Dobersalske, K., Seeger, N. and Willing, H. (ed.) Verantwortliches Wirtschaften: Nachhaltigkeit in der Betriebswirtschaftslehre, Baden-Baden: Nomos.

[34] Waschbusch, G., Kiszka, S. and Hollinger, J. (2020a) 'Chancen und Risiken der Nachhaltigkeitsberichterstattung für Kreditinstitute', BankArchiv - ÖBA, vol. 68 , pp. 406-415.

[35] Waschbusch, G., Kiszka, S. and Runco, F. (2020b) 'Nachhaltigkeitsrisiken und Bankenaufsichtsrecht', Zeitschrift für Bank-und Kapitalmarktrecht, vol. 20, pp. 615-622.

[36] Waschbusch, G., Schuster, H. and Berg, S.C. (2018) Banken und Vertrauen: Eine Grundlagenuntersuchung zur Bedeutung des Vertrauens in der Ökonomie am Beispiel des Kreditgewerbes, Baden-Baden: Nomos.

[37] Weber, M. and Bopp, R.E. (2019) 'Wie ESG die Reputation der Finanzbranche beeinflusst: Reputationsrisiken gewinnen in einem stärker auf Nachhaltigkeit ausgerichteten Finanzmarkt immer mehr an Bedeutung, Börsen-Zeitung, no. 216 , p. B9. 


\section{Summary}

Banks are currently facing numerous challenges. In addition to the ongoing cheap money policy of the European Central Bank, a regulated market environment and a rapidly progressive digitization, financial institutions are increasingly confronted with topics such as sustainability and climate protection. From the latter derive not only risks but also chances for banks. Sustainability risks can impact different risk categories such as market risks, credit risks, operational risks, and liquidity risks. Moreover, reputational risks can occur in this context. This is especially important as bank customers constantly develop a greater awareness of ecological issues, and thus, develop increasing expectations on how companies - like banks - deal with issues like climate protection and sustainability. For this reason, we will start with a theoretical explanation of the key words and then present the results of our customer survey to highlight the current expectations of bank customers in the context of climate protection. Based on this, we formulate recommendations for banks on how to generate a competitive advantage by engaging in climate protection and by taking sustainable actions

JEL codes: G21, M14, M31, O16, Q01, Q50

Keywords: climate protection, climate change, consumer trust, banking 